\title{
Some Economic Aspects of Wheat Crop in Egypt with Emphasis on Baladi Bread Manufacturing in Alexandria Governorate
}

\author{
Gaber Ahmed Bassyouni Shehata and Mamdouh Elbadry Mohamed
}

\begin{abstract}
The baladi bread2 considers an important source to feed the Egyptian population, where is the primary source in his meals food because it is relatively cheap compared to other sources .Although increasing cultivated area of wheat from about 2.5 million feddans in 2003 to about 3.1 million feddans in 2012, but the production is not enough to cover the consumption needs of wheat and flour needed to make baladi bread. The research depends on descriptive and statistical techniques to estimate the numerical coefficients.

As explained in the study results, the evolution of the total number of baladi bakeries in Alexandria governorate, increased with an increase of about 21.4 bakery represents about $1.92 \%$ of the average number of bakeries in Alexandria governorate which was about 1115 bakery during the study period. For the evolution of the total ration of subsidized flour (baladi bakery, warehouses, and other purposes) in Alexandria governorate, it has increased with an increase of about 172 thousand bag annually representing approximately $3.85 \%$ of the average of about 4.5 million bags during the study period.

Several recommendations have been discussed and determined in this search to improve wheat consumption in Egypt.
\end{abstract}

Index Terms-Loaves of bread, consumption, subsidy, bakery.

\section{INTRODUCTION}

Bread is an important source of nutrition, where the individual Egyptian imposed economic and social conditions, eating habits, rely on baladi bread as a source of food meals being considered relatively cheap compared to other alternative sources such as rice, pasta, and in spite of the increase of the cultivated area of wheat from about 2.5 million feddans in 2003 to about 3.1 million feddans in 2012 [1], but its production is not sufficient to cover consumer needs of wheat and flour for baladi bread, and the fact that the total annual production of Egyptian wheat had reached about 8.5 million tons, while the consumption to about 13.5 million tons 2012, has resulted in a low annual production, in addition to the increase in the required amounts of wheat and flour as a result of many factors, the most important is the increase in the population and to a rise in the price of bread in

Manuscript received February 14, 2014; revised April 22, 2014.

Gaber Ahmed Bassyouni Shehata is with the Agricultural Economics Dept., Faculty of Agriculture (Saba Basha), Alexandria University, Egypt (e-mail: drgaber2000@yahoo.com).

Mamdouh Elbadry Mohamed is with the Institute of Agricultural Economic Research Center-Cairo, Egypt (e-mail: mamdouhelbadry2000@yahoo.com).

${ }^{1}$ Bread of limited income or poor people. The subsidized price is 0.05 pound / bread loaf the net weight of bread loaf is 140 gram [1]. low-income and purchasing power, as well as to increase subsidy for baladi bread from about 3.2 billion pounds, 2003/2004 to about 21 billion pound in 2012/2013 [2], [3].

The number of bakeries, deployed in the governorates of Egypt in 2012/2013 was about 19.9 thousand bakery, while the average share of baladi bakery flour backed by about 1.11 tons per day in 2012/2013, The production of bakeries around 226.1 million loaves of bread represent the urban governorates upper Egypt governorates, lower Egypt governorates and border governorates, of which about $21.7 \%$, $36.6 \%, 38.9 \%$ and $2.8 \%$ respectively [4].

The average per capita daily bread in baladi urban governorates, upper governorates, lower governorates and border governorates, of which about 3.5 loaf of bread, 2.3, 3 and 4 loaf of bread a day, respectively, 2012/2013.

The process of making baladi bread faces many problems and difficulties that prevent the attainment of the highest possible efficiency, where the difficulties in changing the exchange rate of Egyptian pound against the US dollar, with increased from about 5.03 pounds per U.S Dollar in 2003 to about 6.10 pounds per U.S Dollar in 2012, , as well as to many of the conflicting policies, such pricing policy, subsidy policy and rationalizing consumption policy, making there is an urgent need to study the economics of baladi bread in Egypt, the most important studies in relation to the interest of the Egyptian national food security [5].

The research problem represented in increasing in world prices for wheat and increase in commodity prices of rice, pasta, alternative of 1.5 pounds $/ \mathrm{kg} 2002 / 2003$ to about 4.25 pounds $/ \mathrm{kg}$ in 2012/2013, in addition to the deterioration of the quality of the baladi bread product to exacerbate the real crisis was how to provide the Egyptian baladi bread per capita with high quality in the average per capita daily bread loaf of about 2.2/day in 2003 to about 2.8 loaf/day in 2012. Despite the increase in the state public budget deficit, which reached about 239.9 billion pounds in 2012, equivalent to about $13.8 \%$ of the gross domestic product compared to about 166.7 billion pounds in 2011, however, the bill food subsidy has increased from about 4.4 billion pounds in 2003 to about 40 billion pounds in 2013 , the increase of food security was due to an increase in the price of exchange rate of the Egyptian pound against the US dollar to nearly 7 pounds in 2013 in light of the high prices of imported wheat and prices rise of domestic supply wheat to about 420 pounds/ardebs in 2013/2014 compared to about 35.3 pounds/ardebs in 2004.

The research problem is in the presence of difficulties and obstacles in industry and production requires baladi bread, and it needs to re-examine the system baladi production of 
bread in Egypt in the increase in the number of bakeries of about 12424 bakery in 2003 to about 19903 bakery in 2012, with an increase of about $60.2 \%$ of its number in 2003, and an increase in the ration of flour baladi subsidized bakeries of about 5.1 million tons in 2003 to about 8 million tons in 2012, with an increase of about $57 \%$ of the quantity in 2003 .

The main objective of the research is studying some aspects of economic wheat crop in Egypt with a focus on the manufacture of bread, Alexandria governorate through study:(1) main indicators of wheat production and consumption in Egypt during the period 1998-2012,(2) development of numbers of the bakeries and the average share of the population in governorates of Egypt for each bakery during the period 2003-2012, (3) studying of total ration of flour subsidized bakeries (baladi, warehouses, other purposes) and the average per capita bread on the level of Egypt (4) development of total production of bakeries on the level of Alexandria governorate during the period 2003 2012, (5) analysis of the relationship between consumer spending on bread as a result of a change in income using the "curve of Angel " through the estimated income elasticity of demand.

For the research methodology it adopted to the method of statistical analysis descriptive and quantitative, as was the use of descriptive analysis to study and analyze the economics of production and manufacture baladi bread in Alexandria Governorate, such as time-series and regression analysis and use Hausmann specification test profile of the quality of the estimated model to determine whether changing user explanatory variable in the model estimated internal variable endogenous or exogenous variable external variables .

The research was based on secondary data obtained from various sources. The search depends on data of time-series to estimate some economic coefficients. The statistical data used in this search are collected from governmental institutions like the Central Agency for Public Mobilization and Statistics, the Ministry of Social Solidarity, and the Ministry of Agriculture and Land Reclamation, as was the use of some references relevant to the subject of the search.

\section{RESEARCH RESULTS AND DISCUSSION}

\section{A. First: Main Indicators of Wheat Production and Consumption in Egypt during the Period 1998-2012}

\section{1) Development of cultivated area productivity,} production and consumption of wheat in Egypt

It appears that the area of wheat in Egypt has increased from about 2.42 million feddans in 1998 to about 3.14 million feddans in 2012, with an increase of about $29.9 \%$, while increased productivity from about 16.78 ardebs in 1998 to about 18 ardebs/feddan in 2012, with an increase of about $7.3 \%$. As for the wheat production has increased from about 6.1 million tons in 1998 to about 8.5 million tons in 2012, with an increase of about $39.4 \%$ (Table I).

TABLE I: DEVElopment of CUltivated AREA, Productivity, PRODUCTION AND CONSUMPTION OF WHEAT IN EGYPT TONS DURING THE PERIOD (1998-2012)

\begin{tabular}{|c|c|c|c|c|}
\hline Year & Cultivated area (feddan) & Productivity (ardeb/feddan) & Production (ardeb) & Production (ton) \\
\hline 1998 & 2421131 & 16.78 & 40621006 & 5971151 \\
\hline 1999 & 2379450 & 17.78 & 42310944 & 6220642 \\
\hline 2000 & 2463265 & 17.77 & 43760352 & 6445053 \\
\hline 2001 & 2341795 & 17.81 & 41697212 & 6408582 \\
\hline 2002 & 2450428 & 18.02 & 44165779 & 6439867 \\
\hline 2003 & 2506178 & 18.21 & 45631282 & 6844692 \\
\hline 2004 & 2605483 & 18.37 & 47852363 & 7177854 \\
\hline 2005 & 2985286 & 18.18 & 54273078 & 8140962 \\
\hline 2006 & 3063701 & 18.00 & 55161517 & 8274228 \\
\hline 2007 & 2715529 & 18.12 & 49192793 & 7378919 \\
\hline 2008 & 2920384 & 18.21 & 53180342 & 7977051 \\
\hline 2009 & 3147028 & 18.06 & 56819969 & 8522995 \\
\hline 2010 & 3001381 & 15.92 & 47793493 & 7169024 \\
\hline 2011 & 3048601 & 18.30 & 55803503 & 8370525 \\
\hline 2012 & 3145234 & 18.00 & 56614212 & 8492132 \\
\hline Average & 2799561 & 18.00 & 50149684 & 7522453 \\
\hline Amount of change & 61721 & 0.0122 & 1125144 & 168772 \\
\hline Rate of change $\%$ & 2.20 & 0.07 & 2.24 & 2.24 \\
\hline$\%$ of change of 1998 & 29.9 & 7.3 & 39.4 & 39.4 \\
\hline
\end{tabular}

The consumption of wheat in Egypt, it has increased from about 10.4 million tons in 1998 to about 13.6 million tons in 2012 , with an increase of about $28.6 \%$, while increasing the wheat gap from about 4.6 million tons in 1998 to about 5.1 million tons in 2012, with an increase of about $11 \%$ (Table II). 
TABLE II: DEVELOPMENT OF PRODUCTION, CONSUMPTION AND WHEAT GAP IN EGYPT DURING THE PERIOD (1998-2012)

\begin{tabular}{cccc}
\hline Year & Production & Consumption & Gap \\
\hline 1998 & 5971 & 10562 & 4591 \\
1999 & 6220 & 9059 & 2839 \\
2000 & 6455 & 10493 & 4038 \\
2001 & 6409 & 9242 & 4533 \\
2002 & 6440 & 11010 & 3498 \\
2003 & 6845 & 10343 & 3927 \\
2004 & 7178 & 11105 & 3854 \\
2005 & 8148 & 12002 & 4466 \\
2006 & 8274 & 12740 & 4842 \\
2007 & 7379 & 12221 & 4779 \\
2008 & 7977 & 12756 & 4284 \\
2009 & 8523 & 12807 & 5754 \\
2010 & 7169 & 12923 & 4941 \\
2011 & 8371 & 13312 & 5095 \\
\hline Average & 8492 & 13587 & 4287 \\
\hline Amount of change & 7323 & 11611 & 122.8 \\
\hline Rate of change \% & 176.3 & 299.1 & 2.86 \\
\hline
\end{tabular}

Source: Compiled and calculated from: (1) Central Agency for Public Mobilization and Statistics www.capmas.gov.eg.(2) Ministry of Agriculture and Land Reclamation, Economic Affairs Sector, central administration agricultural economy, food balance Egypt, different volumes.

2) Development of imports and coverage periods of local production and imports daily consumption of wheat in Egypt during the period (1998 - 2012)

It is clear that Egypt's imports of wheat has increased from about 5.4 million tons in 1998 to about 6.1 million tons in 2012, with an increase of about $12.1 \%$. While the self-sufficiency ratio increased from about $56.5 \%$ in 1998 to about $62.5 \%$ in 2012 , with an increase of about $10.6 \%$. While it was found that daily domestic consumption has increased from about 28.9 thousand tons in 1998 to about 37.2 thousand tons in 2012, with an increase of about $28.7 \%$, it also shows that the period of coverage of local production for consumption had dropped from about 250.6 day in 1999 to about 228.1 day in 2012 , with a decline of about $9 \%$, while it was found that the period of coverage of imports for consumption had dropped from about 222.5 day in 1999 to about 164 day in 2012, with a decline of about $26.3 \%$ (Table III).

TABLE III: DEVOLUTION OF IMPORTS, COVERAGE PERIODS OF LOCAL PRODUCTION AND IMPORTS DAILY CONSUMPTION OF WHEAT IN EGYPT DURING THE PERIOD (1998-2012)

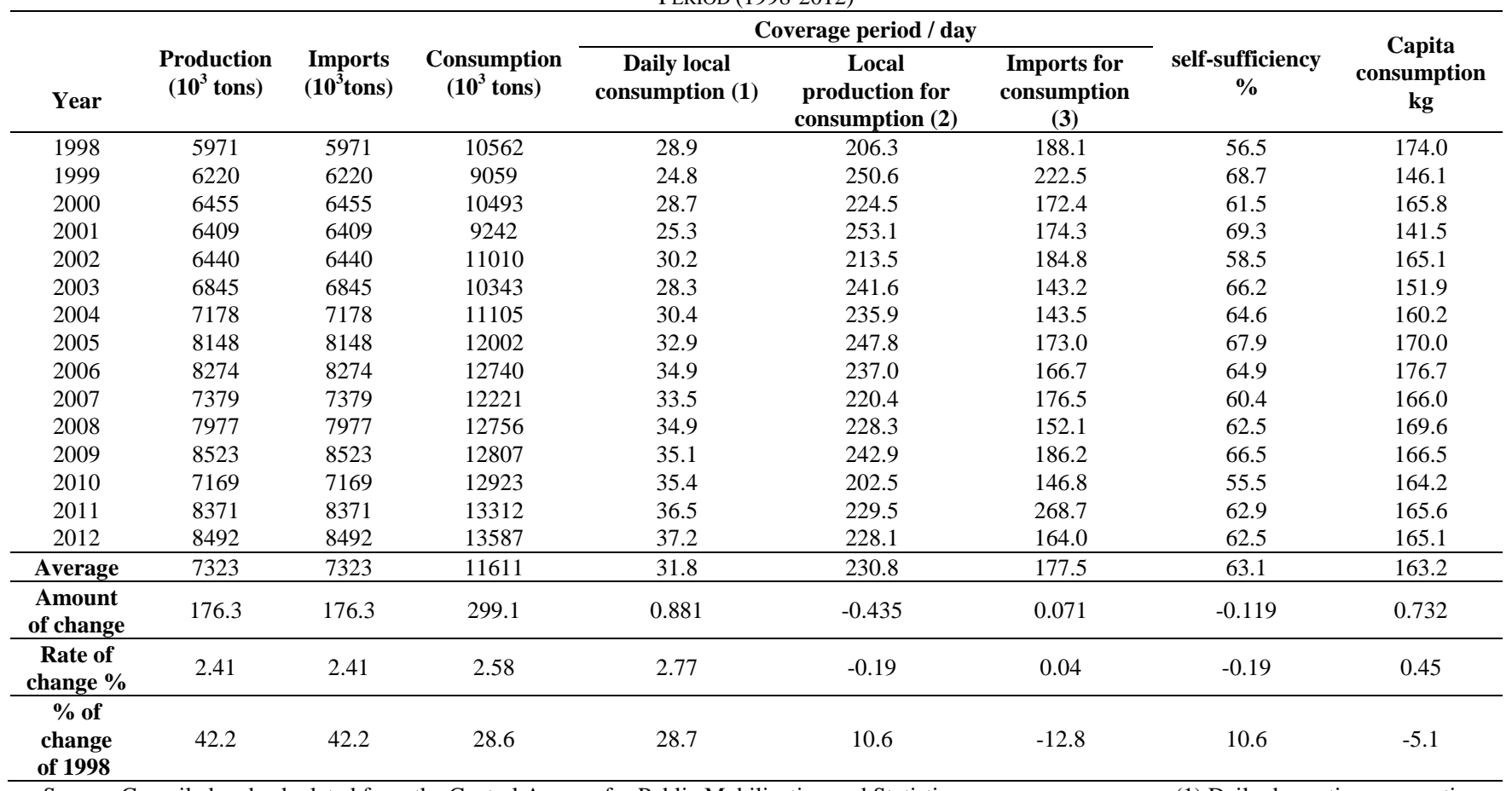

Source: Compiled and calculated from the Central Agency for Public Mobilization and Statistics www.capmas.gov.eg. (1) Daily domestic consumption = domestic consumption / number of days per year. (2) The period of coverage of local production daily consumption = domestic production / daily domestic consumption. (3) The import coverage daily consumption = quantity of imports / domestic consumption daily. 


\section{B. Second: Number of the Bakeries, and the Average}

Bakery Share of the Population in Egypt Governorates

Table IV shows that Cairo governorate was ranked first in the number of bakeries, where it was about 1675 bakeries, while the share of the bakery from the population was about 4941 people, in the second place followed by Menya governorate with about 1885 bakery, while the share of the population of about 2548 people, followed by the third Kafr el-Sheikh governorate with about 1497 bakery, while the share of the population of about 1981 people. In fourth place followed by Giza governorate with about 1479 bakery, while the share of the population of about 4221 people, followed by the fifth Qalyubiyah governorate with about 1468 bakery, while the share of the population of about 3331 people. In the sixth place, followed by Elsharkya governorate with about 1260 bakery, while the share of the population of about 4869 people, followed by the seventh place with Alexandria governorate with about 1200 bakery, while the share of the population of about 3866 people, followed by the rest of the governorates, where the South Sinai governorate in last place with about 33 bakery, while the share of the population of about 5683 people/bakery (Table IV).

TABLE IV: THE NUMBER OF BAKERIES AND THE AVERAGE SHARE OF THE BAKERY FROM THE POPULATION IN GOVERNORATES OF EGYPT FOR A BAKERY IN

\begin{tabular}{|c|c|c|c|c|c|}
\hline Governorate & $\begin{array}{l}\text { Number of } \\
\text { Population }\end{array}$ & $\%$ & No. of bakery & $\%$ & $\begin{array}{c}\text { Share of the bakery from the } \\
\text { population } \\
\text { (people/bakery) }\end{array}$ \\
\hline $\begin{array}{r}\text { Urban governorate: } \\
\text { Cairo }\end{array}$ & 8276551 & 10.2 & 1675 & 8.4 & 4941 \\
\hline Alexandria & 4637664 & 5.7 & 1200 & 6.0 & 3866 \\
\hline Port Saied & 640895.5 & 0.8 & 80 & 0.4 & 7999 \\
\hline Seuz & 585590.9 & 0.7 & 148 & 0.7 & 3957 \\
\hline $\begin{array}{l}\text { Upper governorate: } \\
\text { Dammita }\end{array}$ & 1252493 & 1.5 & 401 & 2.0 & 3122 \\
\hline Dakahlya & 5613788 & 6.9 & 409 & 2.1 & 13717 \\
\hline Elsharkya & 6133863 & 7.6 & 1260 & 6.3 & 4869 \\
\hline Elkalubya & 4889177 & 6.0 & 1468 & 7.4 & 3331 \\
\hline Kafr Elsheich & 2965748 & 3.7 & 1497 & 7.5 & 1981 \\
\hline Charbya & 4492047 & 5.5 & 622 & 3.1 & 7221 \\
\hline Menofya & 3693421 & 4.6 & 977 & 4.9 & 3780 \\
\hline Elbehara & 5388892 & 6.6 & 1022 & 5.1 & 5275 \\
\hline Ismaelya & 1116649 & 1.4 & 742 & 3.7 & 1504 \\
\hline $\begin{array}{c}\text { Lower governorate: } \\
\text { Giza }\end{array}$ & 6241852 & 7.7 & 1479 & 7.4 & 4221 \\
\hline Bany Swaif & 2637478 & 3.3 & 857 & 4.3 & 3078 \\
\hline Fayoum & 2921021 & 3.6 & 580 & 2.9 & 5038 \\
\hline Menya & 4803956 & 5.9 & 1885 & 9.5 & 2548 \\
\hline Asyout & 3945898 & 4.9 & 1194 & 6.0 & 3305 \\
\hline Sohag & 4261362 & 5.3 & 1016 & 5.1 & 4194 \\
\hline Kena & 3105386 & 3.8 & 475 & 2.4 & 6535 \\
\hline Aswan & 1343812 & 1.7 & 365 & 1.8 & 3682 \\
\hline Luxer City & 535315 & 0.7 & 152 & 0.8 & 3511 \\
\hline $\begin{array}{l}\text { Border governorate: } \\
\text { Rde Sea }\end{array}$ & 351893 & 0.4 & 78 & 0.4 & 4517 \\
\hline Elwady Elgdid & 215586 & 0.3 & 65 & 0.3 & 3312 \\
\hline Mrsy Matrouh & 400498 & 0.5 & 121 & 0.6 & 3302 \\
\hline North Sinai & 408496 & 0.5 & 102 & 0.5 & 4014 \\
\hline South Sinai & 188674 & 0.2 & 33 & 0.2 & 5683 \\
\hline Total & 81048007 & 100 & 19903 & 100 & 4072 \\
\hline
\end{tabular}

Source: collected and calculated from: the Central Agency for Public Mobilization and Statistics, unpublished data.

\section{Third: The Total Ration of Flour Subsidized Bakeries} (Baladi, Warehouses, other Purposes) and the Average per Capita Bread on the Level of Egypt during the Period 2003 - 2012

\section{1) Total ration of subsidized flour}

Data in Table V indicate that the total ration of subsidized flour (baladi, warehouses, other purposes) at the level of Egypt had increased by an increase of approximately 2.8 million bag represents about $4.2 \%$ of the average ration of flour backed of about 66.8 million bag during the period of 2003-2012, with an increase of about 57\% [6].

While indicating that the average per capita daily of subsidized bread increased by an increase of about 0.031 bred/day represents about $1.23 \%$ of the average per capita daily of subsidized bread which about 2.5 bread/day during the period 2003-2012, where increased from about 2.2 bread/day in 2003 to about 2.6 bread/day in 2012, with an increase of about $18.2 \%$ (Table V). It should be noted that the amount of the increase in the average per capita of flour backed an increase very low if compared to the increase in the ration, but the population increase has outstripped the increase in the share of flour ration subsidized.

It also shows that the ration of flour backed by $82 \%$ in Alexandria governorate (bakeries, warehouses and other purposes) had increased by an increase of 172 thousand bag annually represent about $3.85 \%$ of the average share of flour ration subsidized by $82 \%$ of Alexandria governorate, about 4.5 million bags during the period 2003-2012, with an increase of about $46.7 \%$ (Table VI). 
TABLE V: TOtAl RATION OF FLOUR SUBSIDIZED BAKERIES (BALADIITY, WAREHOUSES, OTHER PURPOSES) AND THE AVERAGE PER CAPITA BREAD ON THE LEVEL OF EGYPT DURING THE PERIOD 2003-2012.

\begin{tabular}{|c|c|c|c|c|c|}
\hline Year & $\begin{array}{c}\text { Share } \\
\text { (Bag / year) }\end{array}$ & $\begin{array}{c}\text { Production } \\
\left(10^{3} \text { loaf/yaer }\right)\end{array}$ & $\begin{array}{l}\text { number of people per } \\
\text { thousand in mid-year }\end{array}$ & $\begin{array}{l}\text { average per capita } \\
\text { bread/year }\end{array}$ & $\begin{array}{c}\text { average per } \\
\text { capita } \\
\text { bread/day }\end{array}$ \\
\hline 2003 & 51179242 & 52565283 & 65595 & 801 & 2.2 \\
\hline 2004 & 56040526 & 57559108 & 66953 & 860 & 2.4 \\
\hline 2005 & 62687540 & 64384640 & 68342 & 942 & 2.6 \\
\hline 2006 & 65753161 & 67531509 & 71262 & 948 & 2.6 \\
\hline 2007 & 66577372 & 68378758 & 73608 & 929 & 2.5 \\
\hline 2008 & 68598178 & 71317092 & 75229 & 948 & 2.6 \\
\hline 2009 & 68730900 & 73155675 & 76925 & 951 & 2.6 \\
\hline 2010 & 72068573 & 75185240 & 78728 & 955 & 2.6 \\
\hline 2011 & 76516692 & 75702453 & 79603 & 951 & 2.6 \\
\hline 2012 & 80330123 & 77692720 & 81610 & 952 & 2.6 \\
\hline Average & 66848231 & 68347248 & 73786 & 924 & 2.5 \\
\hline Amount of change & 2809396 & 2587662 & 1837.7 & 12.7 & 0.031 \\
\hline Rate of change $\%$ & 4.20 & 3.79 & 2.49 & 1.37 & 1.23 \\
\hline$\%$ of change of 2003 & 57.0 & 47.8 & 24.4 & 18.9 & 18.2 \\
\hline
\end{tabular}

Source: Compiled and computed from: (1) Central Agency for Public Mobilization and Statistics, unpublished data. (2) Ministry of Social Solidarity, unpublished data.

TABLE VI: The TOtAl SHARE OF FlOUR \%82 (BALADI BAKERIES, WAREHOUSES, OTHER PURPOSES) BAG/YEAR DURING THE PERIOD 2003-2012

\begin{tabular}{|c|c|c|c|c|c|c|c|c|c|c|}
\hline Item & 2003 & 2004 & 2005 & 2006 & 2007 & 2008 & 2009 & 2010 & 2011 & 2012 \\
\hline Cairo & 8385903 & 9142913 & 9448045 & 9974811 & 9918144 & 9837112 & 7850257 & 9338461 & 9758924 & 10654171 \\
\hline Alexandria & 3641026 & 3922930 & 4101104 & 4272354 & 4302760 & 4460729 & 4627809 & 4808625 & 5103715 & 5341485 \\
\hline Port Saied & 421082 & 496000 & 547557 & 579955 & 579955 & 604206 & 627727 & 651597 & 687496 & 718171 \\
\hline Seuz & 379633 & 411705 & 516005 & 545411 & 543815 & 568558 & 596194 & 626990 & 660794 & 693843 \\
\hline Total & 12827644 & 13973548 & 14612711 & 15372531 & 15344674 & 15470606 & 13701987 & 15425673 & 16210929 & 17407670 \\
\hline Dammita & 812595 & 882157 & 999447 & 1028372 & 1025027 & 1072179 & 1127032 & 1184287 & 1241002 & 1300581 \\
\hline Dakahlya & 1745463 & 2483680 & 3147187 & 3303110 & 3322112 & 3461525 & 3615601 & 3777774 & 3945094 & 4116055 \\
\hline Elsharkya & 2393468 & 2707821 & 3443148 & 3683087 & 3870515 & 4056280 & 4237414 & 4442870 & 4719507 & 4964387 \\
\hline Elkalubya & 2711965 & 3223766 & 3367491 & 3584368 & 3804340 & 3971816 & 4151264 & 4345943 & 4658988 & 4914808 \\
\hline Kafr Elsheich & 1214479 & 1381155 & 1717266 & 1850872 & 1840568 & 1925037 & 2017186 & 2112239 & 2203575 & 2301792 \\
\hline Charbya & 2110453 & 2249840 & 2663238 & 2815389 & 2886348 & 3006545 & 3124744 & 3257351 & 3403580 & 3546434 \\
\hline Menofya & 1755572 & 1843492 & 2192122 & 2325618 & 2385036 & 2492888 & 2603246 & 2724424 & 2847596 & 2974182 \\
\hline Elbehara & 2088763 & 2503009 & 3048840 & 3062853 & 3146395 & 3293805 & 3461071 & 3628539 & 3790404 & 3964596 \\
\hline Ismaelya & 789870 & 834346 & 911381 & 958208 & 966658 & 1017394 & 1069459 & 1126928 & 1217417 & 1292541 \\
\hline Total & 15622628 & 18109266 & 21490120 & 22611877 & 23246999 & 24297469 & 25407016 & 26600355 & 28027163 & 29375375 \\
\hline Giza & 4794831 & 5051182 & 5647252 & 5925888 & 6094690 & 5861422 & 5520000 & 5643249 & 5749637 & 5866292 \\
\hline Bany Swaif & 1266995 & 1507424 & 1818322 & 1973346 & 1971051 & 2072508 & 2179374 & 2301127 & 2424026 & 2549937 \\
\hline Fayoum & 1845 & 1903423 & 2153561 & 2263039 & 2263283 & 2385802 & 2516743 & 2663373 & 2824146 & 2982676 \\
\hline Menya & 2539565 & 2924385 & 3370020 & 3587937 & 3618670 & 3801432 & 3993628 & 4205472 & 4463082 & 4703695 \\
\hline Asyout & 2688907 & 2814036 & 3168288 & 3326673 & 3315710 & 3482543 & 3651367 & 3840855 & 4049930 & 4254901 \\
\hline Sohag & 3409005 & 3470471 & 3770477 & 3863403 & 3870616 & 4056711 & 4254405 & 4467949 & 4677906 & 4898258 \\
\hline Kena & 2947272 & 2953627 & 3051142 & 3103811 & 3074793 & 3221196 & 3360424 & 2441912 & 3141521 & 3216376 \\
\hline Aswan & 1423710 & 14371 & 1540306 & 15823 & 1589579 & 1658152 & & 1810876 & 1908978 & 1999217 \\
\hline Luxer City & 5 & & 5686 & & & & & & & 249 \\
\hline Total & 21443948 & 22591836 & 25088008 & 26209379 & 26398674 & 27163499 & 27859073 & 28175430 & 30179743 & 31279602 \\
\hline Rde Sea & 235601 & 251373 & 274325 & 283030 & 280393 & 291437 & 303802 & 316453 & 373831 & 408086 \\
\hline Elwady Elgdid & 151879 & 170059 & 185904 & 196351 & 201351 & 210007 & 218790 & 228515 & 247085 & 261170 \\
\hline Mrsy Matrouh & 370231 & 382149 & 419541 & 428825 & 430264 & 456359 & 496553 & 540804 & 593062 & 642542 \\
\hline North Sinai & 409123 & 434903 & 477046 & 492938 & 516788 & 547156 & 578459 & 612190 & 664477 & 708652 \\
\hline South Sinai & 118188 & 127392 & 139885 & 158230 & 158229 & 161644 & 165220 & 169154 & 220403 & 247026 \\
\hline Total & 1285022 & 1365876 & 1496701 & 1559374 & 1587025 & 1666603 & 1762824 & 1867115 & 2098856 & 2267476 \\
\hline Total of Egypt & 51179242 & 56040526 & 62687540 & 65753161 & 66577372 & 68598178 & 68730900 & 72068573 & 76516692 & 80330123 \\
\hline
\end{tabular}

Source: Compiled and computed from: (1) Central Agency for Public Mobilization and Statistics, unpublished data. (2) Ministry of Social Solidarity, unpublished data.

\begin{tabular}{ccc}
\hline Item & Alexandria & Total of Egypt \\
\hline Average (2003-2012) & 4458254 & 66848231 \\
Amount of change & 171706 & 2809396 \\
Rate of change \% & 3.85 & 4.20 \\
\% of change of 2003 & 46.7 & 57.0 \\
\hline
\end{tabular}

Source: Computed from Table VI. 
It should also be noted that the amount of the increase in the average per capita of flour backed by $82 \%$ is very low if it compared with the increase in the ration, but the increase in the population has outstripped the increase in that the ration of flour backed where increased population of Alexandria governorate of about 3.71 million people in 2003 to about 4.64 million in 2012, with an increase of about $25 \%$ of the population of 2003.

\section{1) The annual average per capita daily of baladi bread in Alexandria governorate}

Data in Table VII indicate that the average per capita daily from subsidized bread in Alexandria governorate had increased by an increase of about 0.042 loaf of bread/day represents about $1.39 \%$ of the average per capita daily from subsidized bread in Alexandria governorate, about 3 loaf of bread/day during the period 2003-2012, where increased from about 2.8 loaf of bread/day in 2003 to about 3.3 loaf of bread/day in 2012, with an increase of about $17.9 \%$. As for the average per capita daily subsidized bread in Egypt governorates has increased by an increase of about 0.046 loaf of bread/day represents about $1.8 \%$ of the average per capita daily subsidized bread in governorates of Egypt, about 2.6 loaf of bread/day during the period 2003-2012, where increased from about 2.2 loaf of bread/day in 2003 to about 2.8 loaf of bread/day in 2012, with an increase of about $27.3 \%$ (Table VII).

\begin{tabular}{|c|c|c|c|c|c|c|c|c|c|c|}
\hline Item & 2003 & 2004 & 2005 & 2006 & 2007 & 2008 & 2009 & 2010 & 2011 & 2012 \\
\hline Cairo & 3.2 & 3.5 & 3.5 & 3.5 & 3.5 & 3.5 & 3.1 & 3.4 & 3.5 & 3.6 \\
\hline Alexandria & 2.8 & 2.9 & 3.0 & 3.0 & 2.9 & 3.0 & 3.0 & 3.1 & 3.2 & 3.3 \\
\hline Port Saied & 2.3 & 2.7 & 2.9 & 2.9 & 2.9 & 2.9 & 3.0 & 3.0 & 3.1 & 3.2 \\
\hline Seuz & 2.3 & 2.5 & 3.0 & 3.1 & 2.9 & 3.0 & 3.1 & 3.2 & 3.2 & 3.3 \\
\hline Total & 3.0 & 3.2 & 3.3 & 3.4 & 3.3 & 3.3 & 3.1 & 3.3 & 3.3 & 3.5 \\
\hline Dammita & 2.3 & 2.4 & 2.7 & 2.7 & 2.6 & 2.6 & 2.7 & 2.8 & 2.8 & 2.9 \\
\hline Dakahlya & 1.1 & 1.5 & 1.9 & 1.9 & 1.8 & 1.9 & 1.9 & 2.0 & 2.0 & 2.1 \\
\hline Elsharkya & 1.4 & 1.6 & 1.9 & 2.0 & 2.0 & 2.1 & 2.1 & 2.1 & 2.2 & 2.3 \\
\hline Elkalubya & 2.0 & 2.4 & 2.4 & 2.4 & 2.5 & 2.6 & 2.6 & 2.7 & 2.8 & 2.8 \\
\hline Kafr Elsheich & 1.4 & 1.6 & 1.9 & 2.0 & 1.9 & 2.0 & 2.0 & 2.1 & 2.1 & 2.2 \\
\hline Charbya & 1.6 & 1.7 & 2.0 & 2.0 & 2.0 & 2.0 & 2.1 & 2.1 & 2.2 & 2.2 \\
\hline Menofya & 1.6 & 1.7 & 2.0 & 2.0 & 2.0 & 2.1 & 2.1 & 2.2 & 2.2 & 2.3 \\
\hline Elbehara & 1.4 & 1.6 & 1.9 & 1.9 & 1.9 & 1.9 & 2.0 & 2.0 & 2.0 & 2.1 \\
\hline Ismaelya & 2.7 & 2.8 & 2.9 & 2.9 & 2.8 & 2.9 & 3.0 & 3.0 & 3.2 & 3.2 \\
\hline Total & 1.6 & 1.8 & 2.1 & 2.1 & 2.1 & 2.1 & 2.2 & 2.2 & 2.3 & 2.3 \\
\hline Giza & 2.5 & 2.5 & 2.7 & 2.7 & 2.7 & 2.6 & 2.6 & 2.6 & 2.6 & 2.6 \\
\hline Bany Swaif & 1.7 & 2.0 & 2.4 & 2.5 & 2.4 & 2.4 & 2.5 & 2.6 & 2.6 & 2.7 \\
\hline Fayoum & 2.4 & 2.4 & 2.6 & 2.7 & 2.6 & 2.6 & 2.7 & 2.8 & 2.9 & 2.9 \\
\hline Menya & 1.9 & 2.2 & 2.4 & 2.5 & 2.4 & 2.5 & 2.5 & 2.6 & 2.7 & 2.7 \\
\hline Asyout & 2.4 & 2.5 & 2.7 & 2.8 & 2.7 & 2.7 & 2.8 & 2.9 & 3.0 & 3.0 \\
\hline Sohag & 2.8 & 2.8 & 3.0 & 2.9 & 2.9 & 2.9 & 3.0 & 3.1 & 3.2 & 3.2 \\
\hline Kena & 3.1 & 3.0 & 3.0 & 3.0 & 2.8 & 2.9 & 3.0 & 2.5 & 2.9 & 2.9 \\
\hline Aswan & 3.7 & 3.7 & 3.9 & 3.8 & 3.7 & 3.8 & 3.9 & 4.0 & 4.1 & 4.2 \\
\hline Luxer City & 3.7 & 3.6 & 3.8 & 3.7 & 3.7 & 3.7 & 3.8 & 4.2 & 4.6 & 4.2 \\
\hline Total & 2.5 & 2.6 & 2.8 & 2.8 & 2.7 & 2.7 & 2.8 & 2.8 & 2.9 & 3.0 \\
\hline Rde Sea & 3.1 & 3.1 & 3.2 & 2.9 & 2.7 & 2.7 & 2.8 & 2.9 & 3.1 & 3.3 \\
\hline Elwady Elgdid & 2.6 & 2.9 & 3.0 & 3.0 & 3.0 & 3.0 & 3.1 & 3.2 & 3.3 & 3.4 \\
\hline Mrsy Matrouh & 4.0 & 3.9 & 4.1 & 3.9 & 3.7 & 3.8 & 4.0 & 4.1 & 4.3 & 4.5 \\
\hline North Sinai & 4.0 & 4.1 & 4.3 & 4.2 & 4.2 & 4.3 & 4.5 & 4.6 & 4.8 & 4.9 \\
\hline South Sinai & 3.7 & 3.6 & 3.6 & 3.3 & 3.0 & 3.0 & 3.0 & 3.1 & 3.5 & 3.7 \\
\hline Total & 3.6 & 3.6 & 3.8 & 3.6 & 3.4 & 3.5 & 3.6 & 3.7 & 3.9 & 4.0 \\
\hline Total of Egypt & 2.2 & 2.4 & 2.6 & 2.6 & 2.5 & 2.6 & 2.6 & 2.6 & 2.7 & 2.8 \\
\hline
\end{tabular}

Source: Compiled and computed from: (1) Central Agency for Public Mobilization and Statistics, unpublished data. (2) Ministry of Social Solidarity, unpublished data.

\begin{tabular}{ccc}
\hline Item & Alexandria & Total of Egypt \\
\hline Average (2003-2012) & 3.0 & 2.6 \\
Amount of change & 0.042 & 0.046 \\
Rate of change \% & 1.39 & 1.80 \\
\% of change of $\mathbf{2 0 0 3}$ & 17.9 & 27.3 \\
\hline
\end{tabular}

Source: Computed from Table VII.

D. Fourth: Number of Baladi Bakeries and Quotas Allocated to Them from Subsidized Flour and Bread per Capita Baladi on the Level of Alexandria Governorate in 2012

Alexandria governorate is one of the provinces of civilized cities with a population of approximately about 4.64 million people, and Alexandria governorate administratively divided into six departments ratio: Montazah management, East management, Middle District, West District, Gomrok District and Ameria management. As for the number of baladi bakeries departments ration, occupying management Ameria management ranked first as the number of baladi bakeries with about 307 baladi bakery representing about $25.6 \%$ of the total number of baladi bakeries in Alexandria , followed in the second place Montazah management where the number of baladi bakeries was about 258 representing about $21.5 \%$, followed in third place Middle District where the number of bakeries was about 216 baladi bakery which accounts for 
about $18 \%$, followed by East management in fourth place where the number of bakeries was about 202 baladi representing about $16.8 \%$, followed in fifth place West District where the number of bakeries was about 138 representing about $11.5 \%$, followed by the sixth and final management which was Gomrok District where the number of bakeries was about 79 baladi bakery represent about $6.6 \%$ of the total number of baladi bakeries in Alexandria governorate in 2012 (Table VIII).

TABLE VIII: DISTRIBUTION OF BAKERIES AND QUOTAS RATIONS OF FLOUR SUBSIDIZED DEPARTMENTS IN ALEXANDRIA IN 2012

\begin{tabular}{|c|c|c|c|c|c|c|}
\hline Ration management & $\begin{array}{l}\text { No. of baladi } \\
\text { bakreies }\end{array}$ & $\%$ & $\begin{array}{c}\text { Share } \\
\text { (bag/day) }\end{array}$ & $\%$ & $\begin{array}{l}\text { Production } \\
\left(10^{3} \text { loef of }\right. \\
\text { bread/day })\end{array}$ & $\%$ \\
\hline Ameria & 307 & 25.6 & 2254 & 15.4 & 2339 & 15.4 \\
\hline Montazah & 258 & 21.5 & 2590 & 17.7 & 2689 & 17.7 \\
\hline District Middle & 216 & 18.0 & 2385 & 16.3 & 2476 & 16.3 \\
\hline East management & 202 & 16.8 & 4844 & 33.1 & 5028 & 33.1 \\
\hline West District & 138 & 11.5 & 1610 & 11.0 & 1671 & 11.0 \\
\hline Gomrok District & 79 & 6.6 & 951 & 6.5 & 987 & 6.5 \\
\hline Total & 1200 & 100 & 14634 & 100 & 15190 & 100 \\
\hline
\end{tabular}

Source: Collected and computed from: (1) Central Agency for Public Mobilization and Statistics, unpublished data. (2) Directorate of supply in Alexandria, unpublished data. (3) Egypt's gate informatics www.idsc.gov.eg.

As for the share of flour daily per bag in departments ration, Alexandria governorate registered the management of East ranked first where the share of flour daily by about 4844 bag representing about $33.1 \%$ of the total share of flour daily in Alexandria, followed in second place Montazah management where the share of flour daily by about 2590 bag representing about $17.7 \%$, followed in third place management of Middle District where the share of flour daily by about 2385 bag representing about $16.3 \%$, followed in fourth place Ameria management where the share of flour daily by about 2254 bag representing about $15.4 \%$, followed in fifth place management of West District where the share of flour daily by about 1610 bag account for about $11 \%$, followed by the sixth and final place management of Gomrok District where the share of flour daily by about 951 bag represents about $6.5 \%$ of the total share of flour daily in Alexandria in 2012
(Table VIII).

For the production of daily administrations ration in Alexandria governorate has occupied East management first place where the daily production by about 5.03 million loaves of bread representing about $33.1 \%$ of the total daily production in Alexandria, followed in second place management of Montazah where the daily production by about 2.7 million loaves represent about $17.7 \%$, followed in third place management of Middle District where the daily production by about 2.5 million loaves representing about $16.3 \%$, the fifth place was management of District West where the daily production by about 1.7 million loaves represent about $11 \%$, followed by the sixth and final management of Gomrok District where the production was about 987 thousand loaves representing about $6.5 \%$ of the total daily production in Alexandria in 2012 (Table VIII).

TABLE IX: NUMBER OF BAKERIES AND QUOTAS ALLOCATED TO THEM OF FLOUR SUBSIDIZED BREAD AND THE PER CAPITA LEVEL OF ALEXANDRIA GOVERNORATE DURING THE PERIOD 2003-2012

\begin{tabular}{|c|c|c|c|c|c|c|}
\hline Year & $\begin{array}{l}\text { No. of baladi } \\
\text { bakery(*) }\end{array}$ & $\begin{array}{l}\text { Dailly share } \\
\text { (bag/100 kg) }\end{array}$ & Production / yaer & $\begin{array}{c}\text { Dailly } \\
\text { production }\end{array}$ & $\begin{array}{c}\text { No. of people } \\
\text { (103in mid-year) }\end{array}$ & $\begin{array}{c}\text { average per capita } \\
\text { bread/day }\end{array}$ \\
\hline 2003 & 994 & 9975 & 3779385 & 10354 & 3706 & 2.8 \\
\hline 2004 & 1034 & 10748 & 4072001 & 11156 & 3785 & 2.9 \\
\hline 2005 & 1066 & 11236 & 4256946 & 11663 & 3865 & 3.0 \\
\hline 2006 & 1104 & 11705 & 4434703 & 12150 & 4035 & 3.0 \\
\hline 2007 & 1142 & 11788 & 4466265 & 12236 & 4162 & 2.9 \\
\hline 2008 & 1106 & 12221 & 4630237 & 12686 & 4238 & 3.0 \\
\hline 2009 & 1141 & 12679 & 4803666 & 13161 & 4317 & 3.0 \\
\hline 2010 & 1170 & 13174 & 4991353 & 13675 & 4400 & 3.1 \\
\hline 2011 & 1188 & 13983 & 5297657 & 14514 & 4533 & 3.2 \\
\hline 2012 & 1200 & 14634 & 5544462 & 15190 & 4638 & 3.3 \\
\hline Average & 1115 & 12214 & 4627668 & 12679 & 4168 & 3.0 \\
\hline $\begin{array}{c}\text { Amount of } \\
\text { change }\end{array}$ & 21.4 & 470.4 & 178231 & 488.3 & 104.4 & 0.044 \\
\hline $\begin{array}{c}\text { Rate of } \\
\text { change \% }\end{array}$ & 1.9 & 3.9 & 3.9 & 3.9 & 2.5 & 1.5 \\
\hline $\begin{array}{c}\text { \% of change } \\
\text { of } 2003\end{array}$ & 20.7 & 46.7 & 46.7 & 46.7 & 25.1 & 17.9 \\
\hline
\end{tabular}

Source: Compiled and computed from: (1) Central Agency for Public Mobilization and Statistics, unpublished data. (2) Ministry of Social Solidarity, unpublished data.

(*)Bag production weight of $100 \mathrm{~kg}=1024: 1038$ loaf of bread.

Table IX shows that the number of baladi bakeries in Alexandria governorate has increased with amounted to 
about 21.4 bakery represents about $1.9 \%$ of the average number of bakeries in Alexandria governorate of about 1115 bakery during the period 2003 - 2012, which increased the number of baladi bakeries in Alexandria with about 994 bakery in 2003 to about 1,200 bakery in 2012, with an increase of about $20.7 \%$. While showing that daily quota of subsidized flour $82 \%$ in Alexandria governorate for only baladi bakeries increased by amounted to about 470.2 bag represents about $3.9 \%$ of the average daily quota of subsidized flour $82 \%$ for only baladi bakeries in Alexandria governorate of about 12214 bag during the period 2003-2012, which increased from about 9975 bag in 2003 to about 14634 bag in 2012, with an increase of about 46.7\% [7], [8]. As it turns out that the average daily per capita of subsidized bread in the Alexandria governorate may have increased by amounted to about 0.042 represents about $1.39 \%$ of the average daily share per capita of subsidized bread in Alexandria governorate from subsidized bread with about 3 loaf of bread/ day during the period 2003-2012, which increased from about 2.8 loaf of bread / day in 2003 to about 3.3 loaf of bread / day in 2012, with an increase of about $17.9 \%$ (Table IX).

\section{E. Fifth: Statistical Estimate of Consumer Spending Functions on the Bread in Egypt Using the Search of the Family Budget for the Year 2011/2012}

To estimate the relationship between the total expenditure on bread and consumer income in the Egypt assuming stability of the rest of the determinants of consumption with the exception of total spending where it can derive expenditure elasticity and expenditure consumer [9]-[10], where illustrate the extent of response to changes in spending on the item for the changes in consumer income by examining the family budget. It has been shown that the most appropriate model is written, it was found significant statistical model at the level of probability 0.01 . The determination coefficient was about 0.70 it means that about $70 \%$ of the per capita expenditure on bread due to the change in total spending per capita annual, and appreciated the expenditure elasticity for bread turned out to be the positive amounted to about 0.41 , which means that the bread is one of the essential commodities for Egyptian peoples. The test was conducted Hausman Specification Test to determine the dependant variable is endogenous variable or exogenous variable. It was found from the test quality characterization of the estimated model - using the test Hausman Specification Test for characterization - firming estimates way OLS estimated model.

$$
\begin{aligned}
& Y=590.3+0.02 X \\
& \text { (5.85) (6.43) } \\
& F=41.4 \quad R^{2}=0.70
\end{aligned}
$$

where $Y=$ Total estimated expenditure on bread in Egyptian pound.

$$
X=\text { Total consumer income in Egyptian pound. }
$$

\section{CONCLUSION}

The results of the study recommend the following:

1) The need to increase the ration of subsidized flour in proportion to the increased demand for baladi bread.

2) Taking into account the distribution of rations and the number of population in each governorate of Egypt.

3) Linking the sale of subsidized baladi bread on a national ID card or Supply and linked to the residential consumer address.

4) Attention to the cultivation of improved varieties of wheat and high productivity, reaching the highest productivity per feddan about 23 ardebs.

5) Attention to the cultivation of new land to increase the wheat crop production, which leads to higher self-sufficiency rate of wheat.

6) Encourage the establishment of modern bakeries of high production capacity for subsidized baladi bread in an attempt to reduce the phenomenon of queues.

\section{REFERENCES}

[1] Website of the Ministry of Agriculture and Land Reclamation. [Online]. Available: http://www.agr-egypt.gov.eg

[2] H. Sawalhy, A. Awida, and S. Ahmed, "An economic study for production and consumption of subsidized baladi bread in Sharkia Governorate," in Proc. the Sixteenth Conference of Agricultural Economists, Egyptian Society of Agricultural Economics, Agricultural Club, Dokki, Cairo , 15-16 Octobe, 2008.

[3] H. Rady, "The economics of production and consumption of bread in the Arab Republic of Egypt," Department of Agricultural Economics, Ph.D. Thesis, Faculty of Agriculture, University of Alexandria, 2005.

[4] Website by the Central Agency for Public Mobilization and Statistics. [Online]. Available: http://www.capmas.gov.eg

[5] Website to the main gate of Egypt [Online]. Available: http://www.idsc.gov.eg

[6] S. Zaghloul and G. Shehata, "Economics of the wheat crop in Egypt in the light of local and global variables (globalization)," Egyptian Journal of Agricultural Economics, vol. 11, no. 2, September, 2001.

[7] S. Fouad, "An economic study of grain bread consumption in the rural province of Eastern," Egyptian Journal of Agricultural Economics, vol. XIV, the first issue, March, 2004.

[8] M. Rehan, A. Kenawy, M. Ryad, and H. Sedik, "Expenditure and consumption functions of wheat and its by products in rural and urban Egypt," Egyptian Journal of Agricultural Economics, vol. XVIII, the first issue, March, 2008.

[9] G. Shehata and M. A. Badry, "Appreciation of the record of the demand for citrus using an exemplary application optimized AIDS and demand optimal inverted IAIDS," in Proc. the International Conference XXXV of Statistics and Computer Science and Applications, Statistical Association Egyptian Central Agency for Public Mobilization and Statistics, pp. 11-22, April , 2010.

[10] M. Rehan, "Function expenditure and consumption of wheat and some products in rural and urban of Egypt," Egyptian Journal of Agricultural Economics, vol. 18, no. 1, March, 2008.

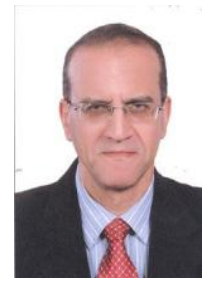

Gaber Shehata was born in Alexandria in 1958. He got his B.Sc. in 1980 at Faculty of agriculture (Saba Basha) Alexandria University, and got his M.Sc in 1988 and Ph. D. in 1994 at the same Faculty and University. He worked as a demonstrator (1980-1988), assistant lecturer (1988-1994), associate prof. (1999-2004) and Prof. Dr. of Agricultural Economics (2004-till naw). He was a chairman of agricultural economics dept. (2009-2012). $\mathrm{He}$ is a membership of Egyptian Society of political economy, statistics and legislation (Cairo, Egypt), member of egyptian association of agricultural economics (Cairo, Egypt) and member of european association of agricultural economics (EAAE). He got on University Prize for Scientific Encouragement for Universal Year 2003. He published many searches in field study and participated in many local and international conferences. 